\title{
The applicability of compost, zeolite and calcium oxide in assisted remediation of acidic soil contaminated with $\mathrm{Cr}(\mathrm{III})$ and $\mathrm{Cr}(\mathrm{VI})$
}

\author{
Maja Radziemska ${ }^{1}$ - Mirosław Wyszkowski ${ }^{2}$ - Agnieszka Bęś ${ }^{3} \cdot$ Zbigniew Mazur $^{2} \cdot$ Jerzy Jeznach $^{1}$ • Martin Brtnický ${ }^{4,5}$
}

Received: 22 February 2019 / Accepted: 16 April 2019 / Published online: 23 May 2019

(C) The Author(s) 2019

\begin{abstract}
The effect of soil amendments, i.e., compost, zeolite, and calcium oxide, on the chemical properties of soil contaminated with $\mathrm{Cr}(\mathrm{III})$ and $\mathrm{Cr}(\mathrm{VI})$ and the uptake of selected heavy metals by spring barley (Hordeum vulgare L.) and maize (Zea mays L.) was determined in a pot experiment. The content of all investigated heavy metals in the tested plants varied significantly in response to the tested soil amendments and increasing concentrations of $\mathrm{Cr}(\mathrm{III})$ and $\mathrm{Cr}(\mathrm{VI})$. Compost, zeolite, and calcium oxide contributed to an increase in the average yield of the aerial parts of maize plants only in treatments contaminated with $\mathrm{Cr}(\mathrm{III})$. The concentrations of $\mathrm{Cr}, \mathrm{Zn}$, and $\mathrm{Ni}$ in the aerial parts of spring barley and maize were higher in treatments contaminated with $\mathrm{Cr}(\mathrm{III})$ than in treatments contaminated with $\mathrm{Cr}(\mathrm{VI})$. Calcium oxide induced a significant increase in soil $\mathrm{pH}$ relative to the control treatment. In treatments without soil amendments, the average $\mathrm{Cr}$ content of soil was higher in pots contaminated with $\mathrm{Cr}(\mathrm{VI})$. The concentrations of $\mathrm{Zn}$ and $\mathrm{Cu}$ in non-amended treatments were negatively correlated with increasing doses of $\mathrm{Cr}(\mathrm{III})$ and $\mathrm{Cr}(\mathrm{VI})$. Calcium oxide decreased the average content of $\mathrm{Cr}, \mathrm{Cu}$, and $\mathrm{Ni}$ in all experimental variants. Compost increased the average content of $\mathrm{Zn}$ in treatments contaminated with $\mathrm{Cr}(\mathrm{III})$ and $\mathrm{Cr}(\mathrm{IV})$ relative to non-amended soil.
\end{abstract}

Keywords Chromium contamination $\cdot$ Soil amendments $\cdot$ Compost $\cdot$ Zeolite $\cdot$ Calcium oxide

\section{Introduction}

Human activities significantly contribute to land transformation (Kintl et al. 2018; Krzyżaniak et al. 2019). In many cases, the

Responsible editor: Tito Roberto Cadaval Jr

Maja Radziemska

maja_radziemska@sggw.pl

1 Department of Environmental Improvement, Faculty of Civil and Environmental Engineering, Warsaw University of Life Sciences SGGW, Nowoursynowska 159, 02-776 Warsaw, Poland

2 Department of Environmental Chemistry, Faculty of Environmental Management and Agriculture, University of Warmia and Mazury in Olsztyn, Pl. Łódzki 4, 10-727 Olsztyn, Poland

3 Department of Chemistry, Research Group of Environmental Toxicology, University of Warmia and Mazury in Olsztyn, Prawocheńskiego 17, 10-720 Olsztyn, Poland

4 Department of Geology and Pedology, Faculty of Forestry and Wood Technology, Mendel University in Brno, Zemědělská 1/1665, 613 00 Brno, Czech Republic

5 Central European Institute of Technology, Brno University of Technology, Purkyňova 656/123, 61200 Brno, Czech Republic resulting changes are immense, and they lead to the degradation of land (Kust et al. 2018; Majewski et al. 2011). Low levels of knowledge about the available land reclamation options are one of the main barriers to recovering disturbed land to its former or other productive uses. Heavy-metal contamination poses a serious environmental threat around the world (Arfaeinia et al. 2019). According to the European Environment Agency, more than $35 \%$ of land in Europe is contaminated with heavy metals (Radziemska et al. 2017a). Chromium (Cr) is a trace element and the twentieth most abundant element on the planet that accounts for $0.037 \%$ of the Earth's crust. It is also the fourth most abundant element in the group of 29 elements which are regarded as critical on account of their biological role and toxicity. Chromium occurs naturally, but it is also released into the environment from anthropogenic sources (Raptis et al. 2018). According to the literature, $\mathrm{Cr}$ compounds in the natural environment can interact with mineral and organic compounds $\mathrm{Hu}$ et al. 2018). Some of these compounds are soluble in water, they are readily transported by surface and underground water, and they are easily dispersed in the natural environment (Wyszkowski and Radziemska 2013).

Naturally occurring $\mathrm{Cr}$ compounds are characterized by various degrees of toxicity. In the environment, $\mathrm{Cr}(\mathrm{VI})$ 
compounds are easily reduced by organic matter to $\mathrm{Cr}$ (III) (Lilli et al. 2019). The biological activity of chromium is determined by its valence state. Chromium compounds are stable in trivalent $(\mathrm{Cr}(\mathrm{III}))$ and hexavalent $(\mathrm{Cr}(\mathrm{VI}))$ states (Jobby et al. 2018). Trivalent chromium compounds are approximately one hundred times less toxic than hexavalent compounds, and only $\mathrm{Cr}(\mathrm{VI})$ compounds are mutagenic (Goswami et al. 2018). In addition to differences in their biological and toxicological properties, the mobility of $\mathrm{Cr}$ compounds in soil and their uptake by plants also differ subject to soil microbiological activity and the organic matter content of soil (Gupta et al. 2018). In most cases, soil reclamation by physical and chemical means is not economically justified, but contaminated soils pose an environmental hazard and cannot be left untreated (He et al. 2019). Phytoremediation ("green remediation") techniques offer an effective alternative. This biological method relies on living plants which degrade (phytodegradation), immobilize (phytostabilization), and remove pollutants from soil (phytoextraction) (Radziemska et al. 2017b).

The application of phytoremediation methods in contaminated areas is a long process because plants differ in their ability to extract and stabilize contaminants (Cameselle and Gouveia 2019). Therefore, soil amendments can be used to increase the effectiveness of phytoremediation and achieve the desired results. The most popular soil amendments include sawdust, biocompost, peat, brown coal, zeolite, phosphorites, apatites, phosphate fertilizers, calcium carbonate, dolomite, and volatile ashes (Ahmad et al. 2012; Li et al. 2019; He et al. 2018; Radziemska and Mazur 2016).

The aim of this study was to determine the applicability of soil amendments such as compost, zeolite, and $\mathrm{CaO}$, in assisted remediation of soil contaminated with $\mathrm{Cr}$ (III) and $\mathrm{Cr}(\mathrm{VI})$ compounds and sown with spring barley (Hordeum vulgare L.) and maize (Zea mays L.).

\section{Materials and methods}

\section{Soil and amendments}

Acidic soil was collected from the top layer $(0-20 \mathrm{~cm})$ of a non-contaminated site in an agricultural area in the vicinity of

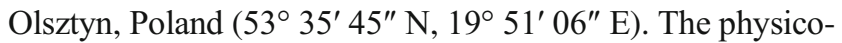
chemical properties of soil samples are presented in Table 1.

The chemical composition of soil amendments used in the experiment is presented in Table 2. Compost and zeolite were added to soil in amounts corresponding to $2.0 \%$ (each) of soil dry mass, and $50 \%$ calcium oxide was added in the amount of $1.25 \mathrm{~g} \mathrm{~kg}^{-1}$ of soil, i.e., a dose corresponding to one unit of hydrolytic acidity (HAC). Soil samples were thoroughly mixed and allowed to stabilize under natural conditions over a period of three weeks before the greenhouse experiment.
Table 1 Selected physicochemical properties of the studied soil

\begin{tabular}{lll}
\hline Property & Unit & Value \\
\hline $\mathrm{pH}$ & - & 4.83 \\
Cation exchange capacity & $\mathrm{cmol} \mathrm{kg}^{-1}$ & 33.75 \\
Texture & - & Fine sand \\
Total organic carbon & $\mathrm{g} \mathrm{kg}^{-1}$ & 7.13 \\
Phosphorous & $\mathrm{mg} \mathrm{kg}^{-1}$ & 46.61 \\
Potassium & $\mathrm{mg} \mathrm{kg}^{-1}$ & 8.22 \\
Magnesium & $\mathrm{mg} \mathrm{kg}^{-1}$ & 33.91 \\
Chromium & $\mathrm{mg} \mathrm{kg}^{-1}$ & 12.95 \\
Copper & $\mathrm{mg} \mathrm{kg}^{-1}$ & 9.01 \\
Zinc & $\mathrm{mg} \mathrm{kg}^{-1}$ & 24.25 \\
Nickel & $\mathrm{mg} \mathrm{kg}^{-1}$ & 3.99 \\
\hline
\end{tabular}

${ }^{\mathrm{c}}$ According to USDA

\section{Greenhouse experiment}

The pot experiment was carried out in the plant growth facility of the University of Warmia and Mazury in Olsztyn. The effect of $\mathrm{Cr}$ (III) and $\mathrm{Cr}(\mathrm{IV})$ as well as compost, zeolite, and calcium oxide on the content of selected heavy metals was evaluated in $9.5 \mathrm{~kg}$ polyethylene pots in a greenhouse experiment. The pots were exposed to natural daylight, temperature of $20-25^{\circ} \mathrm{C}$, and relative humidity of $60-70 \%$. Soil was experimentally contaminated with aqueous solutions of $\mathrm{Cr}(\mathrm{III})$, applied in the form of $\mathrm{KCr}\left(\mathrm{SO}_{4}\right)_{2} \cdot 12 \mathrm{H}_{2} \mathrm{O}$, and $\mathrm{Cr}(\mathrm{VI})$, applied in the form of $\mathrm{K}_{2} \mathrm{Cr}_{2} \mathrm{O}_{7}$, at 0 (control), 25, 50, 100, and $150 \mathrm{mg} \mathrm{kg}^{-1}$ soil. Soil was also enhanced with the following macronutrients and micronutrients (in $\mathrm{mg} \cdot \mathrm{kg}^{-1}$ soil): $\mathrm{N}-110$ $\left[\mathrm{CO}\left(\mathrm{NH}_{2}\right)_{2}+\left(\mathrm{NH}_{4}\right)_{6} \mathrm{Mo}_{7} \mathrm{O}_{24} \cdot 4 \mathrm{H}_{2} \mathrm{O}+\left(\mathrm{NH}_{4}\right)_{2} \mathrm{HPO}_{4}\right] ; \mathrm{P}-50$ $\left[\left(\mathrm{NH}_{4}\right)_{2} \mathrm{HPO}_{4}\right] ; \mathrm{K}-110\left[\mathrm{KCl}+\mathrm{KCr}\left(\mathrm{SO}_{4}\right)_{2} \cdot 12 \mathrm{H}_{2} \mathrm{O}+\right.$ $\left.\mathrm{K}_{2} \mathrm{Cr}_{2} \mathrm{O}_{7}\right] ; \mathrm{Mg}-50\left[\mathrm{MgSO}_{4} \cdot 7 \mathrm{H}_{2} \mathrm{O}\right] ; \mathrm{Mn}-5\left[\mathrm{MnCl}_{2} \cdot 4 \mathrm{H}_{2} \mathrm{O}\right]$; $\mathrm{Mo}-5\left[\left(\mathrm{NH}_{4}\right)_{6} \mathrm{Mo}_{7} \mathrm{O}_{24} \cdot 4 \mathrm{H}_{2} \mathrm{O}\right] ; \mathrm{B}-0.33\left[\mathrm{H}_{3} \mathrm{BO}_{3}\right]$. The experiment had a completely randomized block design with four replicates per treatment. The tested plants were spring barley (Hordeum vulgare L.) cv. Ortega (main crop) and maize (Zea mays L.) cv. Fripon (successive crop). The main crop was sown at 15 plants per pot, and the successive crop at 8 plants

Table 2 Chemical composition of soil amendments used in the experiment

\begin{tabular}{lllll}
\hline Property & Unit & Compost & Zeolite & Calcium oxide \\
\hline Phosphorous & $\mathrm{g} \mathrm{kg}^{-1}$ & 2.32 & 0.11 & 0.10 \\
Potassium & $\mathrm{g} \mathrm{kg}^{-1}$ & 1.33 & 23.21 & 0.77 \\
Magnesium & $\mathrm{g} \mathrm{kg}^{-1}$ & 1.47 & 0.31 & 2.65 \\
Chromium & $\mathrm{mg} \mathrm{kg}^{-1}$ & 3.48 & 1.81 & 2.70 \\
Copper & $\mathrm{mg} \mathrm{kg}^{-1}$ & 38.13 & $12.38 \mathrm{~s}$ & 2.26 \\
Zinc & $\mathrm{mg} \mathrm{kg}^{-1}$ & 31.80 & 14.68 & 5.14 \\
Nickel & $\mathrm{mg} \mathrm{kg}^{-1}$ & 18.75 & 408.7 & 6.64 \\
\hline
\end{tabular}


per pot. The plants were irrigated with distilled water to maintain soil moisture content at $60 \%$ capillary water capacity. Spring barley was harvested in the heading stage, and maize was harvested in the stem elongation stage on days 56 and 67 of the growing season, respectively. The weight of aerial plant parts was determined at harvest. The harvested biomass was dried, ground, and subjected to chemical analyses.

\section{Sample preparation and chemical analysis}

Soil samples were air-dried and sieved $(<1 \mathrm{~mm})$. Plant material was washed with distilled water and oven-dried at $70{ }^{\circ} \mathrm{C}$. Dried plant material was ground in an analytical mill (Retsch type ZM 300, Hann, Germany). The following soil parameters were determined before the experiment and at harvest: $\mathrm{pH}$ was determined in a 1:5 w/v suspension in distilled water with a $\mathrm{pH}$ meter (Model EA940, Orion, USA), total N was determined by the Kjeldahl (1983) method, total organic carbon (TOC) was determined after dichromate oxidation of samples and titration with ferrous ammonium sulfate (Walkley and Black 1934), available $P$ was determined in a colorimetric analysis with the vanadium-molybdenum method (Cavell 1955), K was determined by atomic emission spectrometry (AES), and $\mathrm{Mg}$ was determined by atomic absorption spectrometry (AAS) (Szyszko 1982). Total Cr, Cu, Zn, and Ni content was determined with the SpectrAA 240FS (VARIAN, Australia) atomic absorption spectrophotometer after digestion of triplicate samples in $\mathrm{HNO}_{3}$ in the MARS 5 microwave oven (CEM Corporation, USA) with a modified version of the EPA 3051A method (U.S. Environmental Protection Agency 2007). The analyses were conducted with the use of deionized water with conductivity of $0.055 \mu \mathrm{S} \mathrm{cm}^{-1}$, purified in the Crystal 10 system (Aldrona Laboratory System). Certified reference material (Sigma Aldrich Chemie GmbH, No. BCR142R) was used in the analyses. Before the experiment, laboratory equipment was treated with $5 \mathrm{~mol} \mathrm{~L}^{-1} \mathrm{HNO}_{3}$ for $24 \mathrm{~h}$ and rinsed with ultrapure water.

\section{Statistical analyses}

The normal distribution of variables in every independent group was checked in the Shapiro-Wilk test, and the normality of the residuals was verified. The homogeneity of variance was checked in Levene's test. Factorial ANOVA ( $F$-test) was conducted. The experimental factors were chromium valence, chromium dose, and soil amendments. The significance of differences was determined in Tukey's test $(p<0.05)$. The relationships between selected parameters were determined by calculating Pearson's correlation coefficient $r$ between two variables. The calculated values of $r$ were regarded as significant at $p<0.05$. The relationships between selected parameters were determined by correlation analysis and linear regression analysis with three variables. The results were processed in the Statistica 12.0 program (StatSoft Inc. 2017).

\section{Results}

\section{The effect of $\mathrm{Cr}(\mathrm{III})$ and $\mathrm{Cr}(\mathrm{VI})$ contamination on dry biomass yield}

Crop yields differed significantly in response to soil contamination with various forms of $\mathrm{Cr}$ (Tables 3 and 4). Spring barley (main crop) in treatments without soil amendments was highly sensitive to contamination with $\mathrm{Cr}(\mathrm{VI})$ (Fig. 1). The reverse was noted in maize (successive crop) where increasing doses of $\mathrm{Cr}(\mathrm{III})$ and, in particular, $\mathrm{Cr}(\mathrm{VI})$ induced a significant increase in yield. $\mathrm{Cr}$ (III) doses of 100 and $150 \mathrm{mg}$ $\mathrm{kg}^{-1}$ soil decreased the weight of the aerial parts of spring barley by $21 \%$ and $31 \%$, respectively, relative to the control treatment. The $\mathrm{Cr}(\mathrm{VI})$ dose of $150 \mathrm{mg} \mathrm{kg}^{-1}$ soil caused a $95 \%$ decrease in the above parameter. Maize yields were highest under exposure to a $\mathrm{Cr}(\mathrm{VI})$ dose of $100 \mathrm{mg} \mathrm{kg}^{-1}$ soil.

The multiple regression analysis of soil contamination with $\mathrm{Cr}(\mathrm{III})$ and $\mathrm{Cr}(\mathrm{VI})$ revealed that barley yields were influenced by $\mathrm{Cr}$ dose and soil $\mathrm{pH}$ in pots contaminated with $\mathrm{Cr}(\mathrm{III})$ and by soil $\mathrm{pH}$ in pots contaminated with $\mathrm{Cr}(\mathrm{VI})$. The spring barley model with $R^{2}$ of 0.87 and standard error of estimation of 16.0 was characterized by the highest goodness of fit (Fig. 2). Maize yields were determined by soil $\mathrm{pH}$, whereas the influence of $\mathrm{Cr}(\mathrm{III})$ and $\mathrm{Cr}(\mathrm{VI})$ doses was not significant (not shown).

\section{The effect of $\mathrm{Cr}(\mathrm{III})$ and $\mathrm{Cr}(\mathrm{VI})$ contamination on the heavy-metal content of plants}

The Cr content of the aerial parts of spring barley (main crop) and maize (successive crop) was significantly affected by $\mathrm{Cr}(\mathrm{III})$ and $\mathrm{Cr}(\mathrm{VI})$ doses (Table 5). The average $\mathrm{Cr}$ content of the aerial parts of spring barley in pots without soil amendments was nearly twice higher in pots contaminated with $\mathrm{Cr}(\mathrm{III})$ than in pots contaminated with $\mathrm{Cr}(\mathrm{VI})$. The reverse was noted in maize (successive crop), where the $\mathrm{Cr}$ content of aerial plant parts was three times higher in pots contaminated with $\mathrm{Cr}(\mathrm{VI})$ than in $\mathrm{Cr}(\mathrm{III})$ treatments. $\mathrm{Cr}(\mathrm{III})$ exerted a greater influence on the $\mathrm{Cr}$ content of the aboveground biomass of spring barley, where $\mathrm{Cr}(\mathrm{III})$ doses of 100 and $150 \mathrm{mg} \mathrm{kg}^{-1}$ soil led to a 5-fold increase in $\mathrm{Cr}$ concentration relative to the control treatment. In treatments without soil amendments, an increase in $\mathrm{Cr}(\mathrm{III})$ and $\mathrm{Cr}(\mathrm{VI})$ doses increased the $\mathrm{Cr}$ content of the aerial biomass of maize. The increase was higher in pots contaminated with $\mathrm{Cr}(\mathrm{VI})$ where $\mathrm{Cr}$ concentration increased nearly 17 -fold relative to the control treatment (without $\mathrm{Cr}$ ). 
Table 3 Analysis of variance ( $F$-test) of heavy-metal content in aboveground parts of spring barley

\begin{tabular}{|c|c|c|c|c|c|c|c|c|c|c|}
\hline \multirow[t]{2}{*}{ Source of variation } & \multicolumn{2}{|l|}{$\mathrm{Cr}$} & \multicolumn{2}{|l|}{$\mathrm{Cu}$} & \multicolumn{2}{|l|}{$\mathrm{Zn}$} & \multicolumn{2}{|l|}{$\mathrm{Ni}$} & \multicolumn{2}{|c|}{ Biomass yield } \\
\hline & $F$ & $p$ value & $F$ & $p$ value & $F$ & $p$ value & $F$ & $p$ value & $F$ & $p$ value \\
\hline $\mathrm{V}$ & $17711.8^{* *}$ & $<0.001$ & $39393.4 * *$ & $<0.001$ & $3296.7 * *$ & $<0.001$ & $6509.5^{* *}$ & $<0.001$ & $6634.4 * *$ & $<0.001$ \\
\hline $\mathrm{D}$ & $5335.4 * *$ & $<0.001$ & $5866.9 * *$ & $<0.001$ & $1973.0^{* * *}$ & $<0.001$ & $913.9^{* *}$ & $<0.001$ & $2432.9 * *$ & $<0.001$ \\
\hline SA & $8994.0 * *$ & $<0.001$ & $3961.3 * *$ & $<0.001$ & $422.2 * *$ & $<0.001$ & $2371.7 * *$ & $<0.001$ & $463.6^{* *}$ & $<0.001$ \\
\hline $\mathrm{V} \times \mathrm{D}$ & $1369.4 * *$ & $<0.001$ & $2672.0 * *$ & $<0.001$ & $261.2 * *$ & $<0.001$ & $468.6^{* *}$ & $<0.001$ & $1375.5 * *$ & $<0.001$ \\
\hline $\mathrm{V} \times \mathrm{SA}$ & $12702.1 * *$ & $<0.001$ & $6385.5 * *$ & $<0.001$ & $350.4 * *$ & $<0.001$ & $6485.9 * *$ & $<0.001$ & $33.1 * *$ & $<0.001$ \\
\hline $\mathrm{D} \times \mathrm{SA}$ & $417.0 * *$ & $<0.001$ & $543.2 * *$ & $<0.001$ & $65.6^{* *}$ & $<0.001$ & $490.0 * *$ & $<0.001$ & $76.6^{* *}$ & $<0.001$ \\
\hline $\mathrm{V} \times \mathrm{D} \times \mathrm{SA}$ & $1007.8 * *$ & $<0.001$ & $710.1 * *$ & $<0.001$ & $44.8^{* *}$ & $<0.001$ & $523.0^{* *}$ & $<0.001$ & $34.5 * *$ & $<0.001$ \\
\hline
\end{tabular}

$\mathrm{V}-\mathrm{Cr}(\mathrm{III}), \mathrm{Cr}(\mathrm{VI})$. D — dose of Cr. SA — soil amendments. $\mathrm{V} \times \mathrm{D}, \mathrm{V} \times \mathrm{SA}, \mathrm{D} \times \mathrm{SA}, \mathrm{V} \times \mathrm{D} \times \mathrm{SA}$-interactions between the factors. *Significant at $p<0.05$;

**significant at $p<0.01$. ns - not significant

Both $\mathrm{Cr}(\mathrm{III})$ and $\mathrm{Cr}(\mathrm{VI})$ significantly affected the $\mathrm{Cu}$ content of the aerial parts of spring barley and maize (Table 5). In treatments without soil amendments, the average $\mathrm{Cu}$ content of the aboveground biomass of spring barley (main crop) was somewhat higher in $\mathrm{Cr}(\mathrm{VI})$ treatments than in $\mathrm{Cr}(\mathrm{III})$ treatments. In pots without soil amendments, the $\mathrm{Cu}$ content of the aerial parts of spring barley was positively correlated with increasing doses of $\mathrm{Cr}$ (III) which induced a nearly 3 -fold increase in $\mathrm{Cu}$ concentration. $\mathrm{Cr}$ (III) exerted a greater influence on the $\mathrm{Cu}$ content of maize, and the $\mathrm{Cr}$ (III) dose of $100 \mathrm{mg}$ $\mathrm{kg}^{-1}$ soil increased the analyzed parameter by $78 \%$ relative to the control treatment. Higher doses of $\mathrm{Cr}$ (III) decreased the $\mathrm{Cu}$ content of maize.

In treatments without soil amendments, the average $\mathrm{Zn}$ content of the aboveground parts of spring barley and maize was higher in pots contaminated with $\mathrm{Cr}(\mathrm{III})$ than in $\mathrm{Cr}(\mathrm{VI})$ treatments (Table 5). In treatments without soil amendments, $\mathrm{Cr}(\mathrm{VI})$ exerted a minimally greater influence on the $\mathrm{Zn}$ content of the aerial biomass of spring barley. The $\mathrm{Cr}(\mathrm{VI})$ dose of $150 \mathrm{mg} \mathrm{kg}^{-1}$ soil decreased $\mathrm{Zn}$ concentration in spring barley by $46 \%$ relative to the control treatment (without $\mathrm{Cr}$ ). The accumulation of $\mathrm{Zn}$ in the aboveground parts of spring barley in treatments without soil amendments was negatively correlated with increasing doses of $\mathrm{Cr}(\mathrm{III})$. In these treatments, the $\mathrm{Cr}$ (III) dose of $150 \mathrm{mg} \mathrm{kg}^{-1}$ soil decreased $\mathrm{Zn}$ content by $44 \%$ relative to the control treatment (without $\mathrm{Cr}$ ). In non-amended treatments contaminated with $\mathrm{Cr}(\mathrm{VI})$, the decrease in the $\mathrm{Zn}$ content of maize was similar to that noted in spring barley, whereas $\mathrm{Cr}(\mathrm{III})$ exerted a far smaller influence.

In treatments without soil amendments, the average $\mathrm{Ni}$ content of the aboveground parts of spring barley and maize was higher in pots contaminated with $\mathrm{Cr}(\mathrm{III})$ than in $\mathrm{Cr}(\mathrm{VI})$ treatments (Table 5). $\mathrm{Cr}(\mathrm{VI})$ exerted a greater influence on the $\mathrm{Ni}$ content of spring barley in non-amended treatments than $\mathrm{Cr}(\mathrm{III})$. The accumulation of $\mathrm{Ni}$ in the aerial biomass of spring barley (main crop) in non-amended treatments was negatively correlated with increasing doses of $\mathrm{Cr}(\mathrm{III})$ and $\mathrm{Cr}(\mathrm{VI})$. In these treatments, $\mathrm{Cr}(\mathrm{VI})$ doses of 100 and $150 \mathrm{mg} \mathrm{kg}^{-1}$ soil led to a nearly 9-fold and 15-fold decrease in Ni concentrations in the aerial parts of spring barley, respectively, relative to the control treatment (without $\mathrm{Cr}$ ). $\mathrm{Cr}$ (III) caused an over 2 -fold and 3 -fold decrease in the Ni content of spring barley, respectively. $\mathrm{Cr}(\mathrm{VI})$ exerted a greater influence on maize (successive crop) than on spring barley. The highest dose of $\mathrm{Cr}(\mathrm{III})$ and

Table 4 Analysis of variance ( $F$-test) of heavy-metal content in aboveground parts of maize

\begin{tabular}{|c|c|c|c|c|c|c|c|c|c|c|}
\hline \multirow[t]{2}{*}{ Source of variation } & \multicolumn{2}{|l|}{$\mathrm{Cr}$} & \multicolumn{2}{|l|}{$\mathrm{Cu}$} & \multicolumn{2}{|l|}{$\mathrm{Zn}$} & \multicolumn{2}{|l|}{$\mathrm{Ni}$} & \multicolumn{2}{|c|}{ Biomass yield } \\
\hline & $F$ & $p$ value & $F$ & $p$ value & $F$ & $p$ value & $F$ & $p$ value & $F$ & $p$ value \\
\hline $\mathrm{V}$ & $8959.2 * *$ & $<0.001$ & $7562.8^{* *}$ & $<0.001$ & $8345.4 * *$ & $<0.001$ & $1401.96 * *$ & $<0.001$ & $3479 * *$ & $<0.001$ \\
\hline $\mathrm{D}$ & $604.9 * *$ & $<0.001$ & $136.3 * *$ & $<0.001$ & $1199.0 * *$ & $<0.001$ & $6493.05 * *$ & $<0.001$ & $2066^{* *}$ & $<0.001$ \\
\hline SA & $2391.2 * *$ & $<0.001$ & $240.7 * *$ & $<0.001$ & $11070.6^{* *}$ & $<0.001$ & $9492.36 * *$ & $<0.001$ & $622 * *$ & $<0.001$ \\
\hline $\mathrm{V} \times \mathrm{D}$ & $721.7 * *$ & $<0.001$ & $770.2 * *$ & $<0.001$ & $564.5^{* *}$ & $<0.001$ & $299.47 * *$ & $<0.001$ & $2093 * *$ & $<0.001$ \\
\hline $\mathrm{V} \times \mathrm{SA}$ & $14104.5 * *$ & $<0.001$ & $412.5^{* *}$ & $<0.001$ & $3992.3 * *$ & $<0.001$ & $1740.52 * *$ & $<0.001$ & $3046^{* *}$ & $<0.001$ \\
\hline $\mathrm{D} \times \mathrm{SA}$ & $1014.6^{* *}$ & $<0.001$ & $212.3^{* *}$ & $<0.001$ & $442.6^{* *}$ & $<0.001$ & $7073.30 * *$ & $<0.001$ & $1831 * *$ & $<0.001$ \\
\hline $\mathrm{V} \times \mathrm{D} \times \mathrm{SA}$ & $995.3 * *$ & $<0.001$ & $117.6^{* *}$ & $<0.001$ & $619.4^{* *}$ & $<0.001$ & $269.17 * *$ & $<0.001$ & $1066^{* *}$ & $<0.001$ \\
\hline
\end{tabular}

$\mathrm{V}-\mathrm{Cr}(\mathrm{III}), \mathrm{Cr}(\mathrm{VI}) . \mathrm{D}$ - dose of Cr. SA — soil amendments. $\mathrm{V} \times \mathrm{D}, \mathrm{V} \times \mathrm{SA}, \mathrm{D} \times \mathrm{SA}, \mathrm{V} \times \mathrm{D} \times \mathrm{SA}$-interactions between the factors. *Significant at $p<0.05$;

**significant at $p<0.01$. ns - not significant 

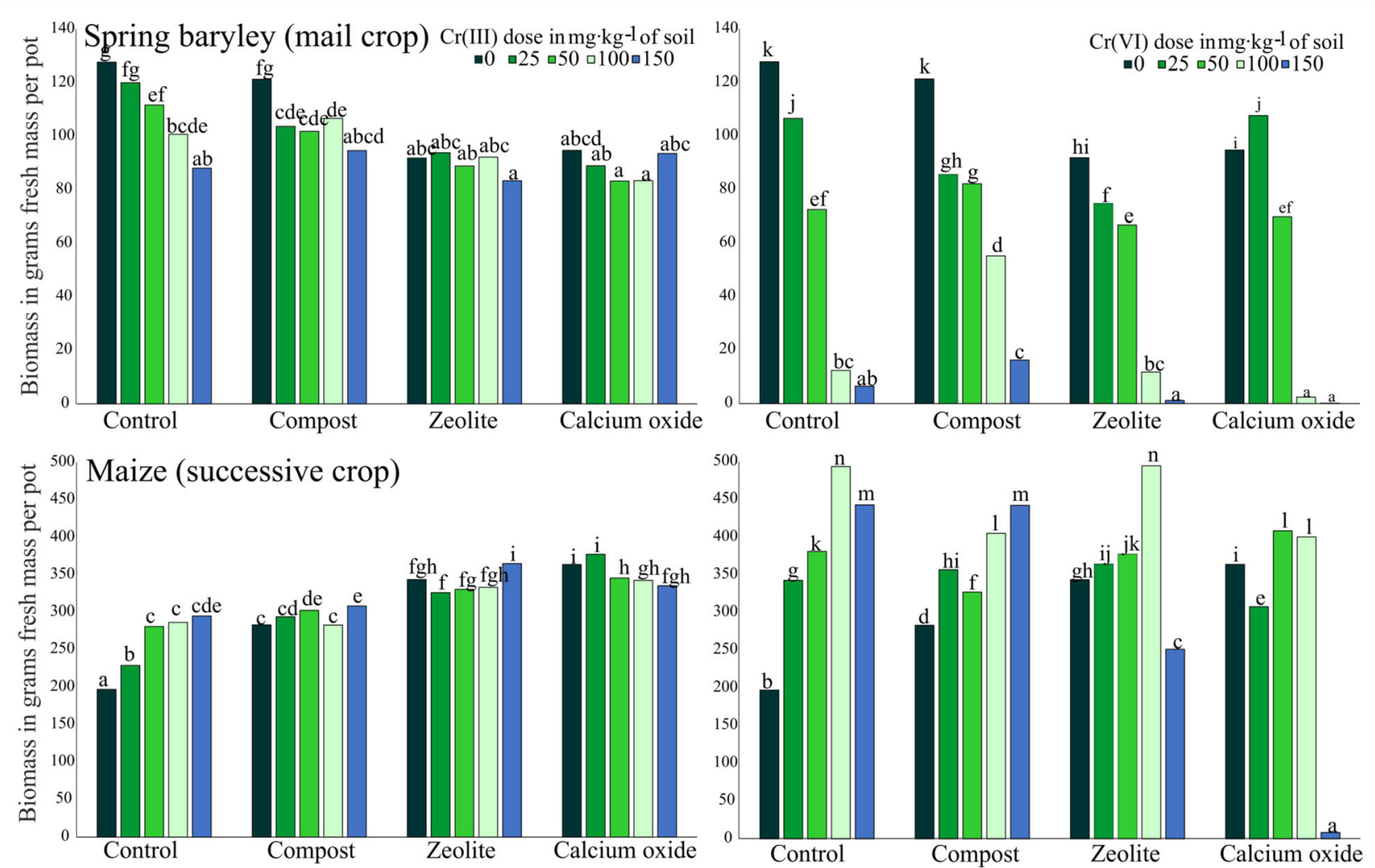

Fig 1 The biomass yields of spring barley (main crop) and maize (successive crop) in pots contaminated with different doses of $\mathrm{Cr}(\mathrm{III})$ and $\mathrm{Cr}(\mathrm{VI})(0 ; 25$; $50 ; 150 \mathrm{mg} \mathrm{kg}^{-1}$ soil). Different letters above the columns indicated significant difference at the $p<0.05$

Cr(IV) - $150 \mathrm{mg} \mathrm{kg}^{-1}$ soil—decreased the Ni content of maize by $98 \%$ and $96 \%$, respectively, relative to the control treatment (without $\mathrm{Cr}$ ).

\section{The effect of soil amendments on dry biomass yield}

The application of compost, zeolite, and calcium oxide in $\mathrm{Cr}(\mathrm{III})$ and $\mathrm{Cr}(\mathrm{VI})$ treatments did not improve crop yields. Soil amendments increased the average yield of the aerial biomass of maize only in pots contaminated with $\mathrm{Cr}$ (III) relative to the control treatment (Fig. 1). The application of calcium oxide in pots with the highest $\mathrm{Cr}(\mathrm{VI})$ dose of $150 \mathrm{mg}$ $\mathrm{kg}^{-1}$ soil nearly completely inhibited the yielding of both crops.

\section{The effect of soil amendments on the heavy-metal content of plants}

Compost, zeolite, and calcium oxide significantly affected the $\mathrm{Cr}$ content of the aerial parts of spring barley (main crop) and maize (successive crop) (Table 5). In treatments contaminated with $\mathrm{Cr}(\mathrm{III})$, all soil amendments decreased the average $\mathrm{Cr}$ concentration in the aboveground parts of spring barley. Compost was most effective $(74 \%)$, whereas zeolite and calcium oxide (54\%) were less-effective soil amendments. In pots contaminated with $\mathrm{Cr}(\mathrm{VI})$, only compost contributed to a $40 \%$ decrease in the $\mathrm{Cr}$ content of the aerial biomass of spring barley, whereas zeolite and calcium oxide increased $\mathrm{Cr}$ accumulation 3-fold and more than 2-fold, respectively, relative to the control treatment (without soil amendments). Compost $(-78 \%)$, zeolite ($77 \%)$, and calcium oxide $(-75 \%)$ exerted the greatest influence on the $\mathrm{Cr}$ content of the aerial biomass of maize in treatments contaminated with $\mathrm{Cr}(\mathrm{VI})$, relative to the control treatment. In pots contaminated with $\mathrm{Cr}(\mathrm{III})$, all of the tested soil amendments increased $\mathrm{Cr}$ accumulation in maize, and the greatest increase was caused by calcium oxide and zeolite.

Compost, zeolite, and calcium oxide significantly influenced the $\mathrm{Cu}$ content of the aerial biomass of the tested crops in pots contaminated with $\mathrm{Cr}(\mathrm{III})$ and $\mathrm{Cr}(\mathrm{VI})$ (Table 5). In these treatments, compost, zeolite (only in $\mathrm{Cr}(\mathrm{VI})$ treatments), and calcium oxide increased the average $\mathrm{Cr}$ concentration in the aboveground parts of spring barley relative to the control treatment (without soil amendments). The addition of compost to pots with $\mathrm{Cr}(\mathrm{III})$ and the addition of zeolite to pots with $\mathrm{Cr}(\mathrm{VI})$ induced the highest increase in the $\mathrm{Cu}$ content of spring barley by $44 \%$ and $147 \%$, respectively. The analyzed soil amendments exerted a greater influence on maize in 


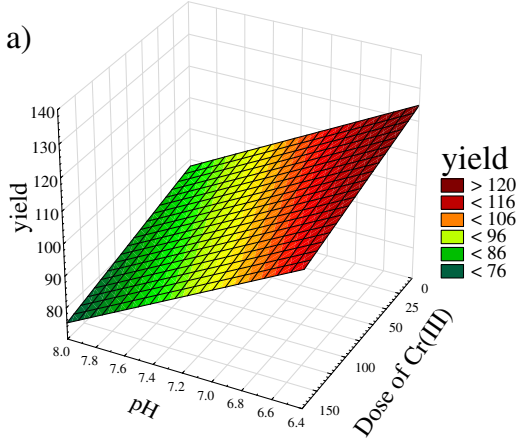

Regression model $\mathrm{z}=\mathrm{b}_{0}+\mathrm{b}_{1} \cdot \mathrm{x}+\mathrm{b}_{2} \cdot \mathrm{y}$ Estimated parameters: $b_{0}=273.5255$, $b_{1}=-23.2206, b_{2}=-0.0786, R^{2}=0.4699$ ANOVA: $\mathrm{F}=16.4018, \mathrm{p}=7.9 \cdot 10^{-6}, \mathrm{SEE}=9.8$

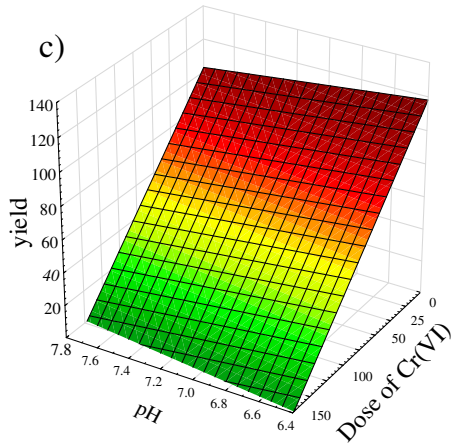

Regression model $\mathrm{z}=\mathrm{b}_{0}+\mathrm{b}_{1} \cdot \mathrm{x}+\mathrm{b}_{2} \cdot \mathrm{y}$

Estimated parameters: $b_{0}=189.0057, b_{1}=-11.0755$, $\mathrm{b}_{2}=-0.7461, \mathrm{R}^{2}=0.87$

ANOVA: $\mathrm{F}=123.9158, \mathrm{p}=3.99 \cdot 10^{-17}, \mathrm{SEE}=16.0$ b)

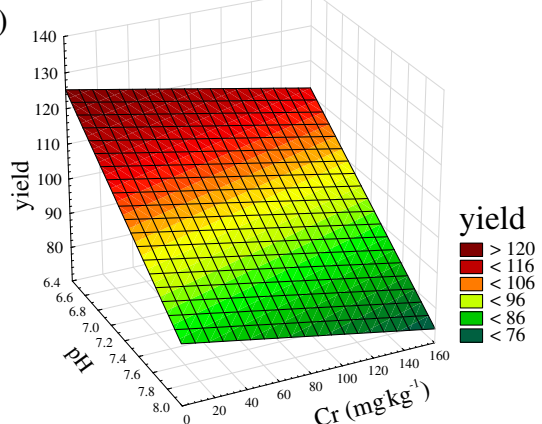

Regression model $\mathrm{z}=\mathrm{b}_{0}+\mathrm{b}_{1} \cdot \mathrm{x}+\mathrm{b}_{2} \cdot \mathrm{y}$

Estimated parameters: $b_{0}=277.23, b_{1}=-23.7373$, $\mathrm{b}_{2}=-0.7461, \mathrm{R}^{2}=0.4473$

ANOVA: $\mathrm{F}=14.9766, \mathrm{p}=1.7 \cdot 10^{-5}, \mathrm{SEE}=9.9$

d)

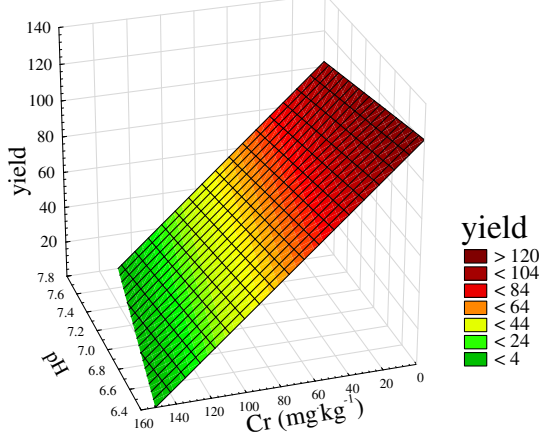

Regression model $\mathrm{z}=\mathrm{b}_{0}+\mathrm{b}_{1} \cdot \mathrm{x}+\mathrm{b}_{2} \cdot \mathrm{y}$

Estimated parameters: $b_{0}=206.7458, b_{1}=-13.3293$,

$\mathrm{b}_{2}=-0.7994, \mathrm{R}^{2}=0.8347$

ANOVA: $\mathrm{F}=93.4661, \mathrm{p}=3.42 \cdot 10^{-15}, \mathrm{SEE}=18.0$

Fig. 2 The relationship between spring barley biomass yield vs. Cr dose and soil pH. SEE, standard error of estimation

treatments contaminated with $\mathrm{Cr}(\mathrm{VI})$ than $\mathrm{Cr}(\mathrm{III})$. In pots with $\mathrm{Cr}(\mathrm{VI})$, compost, calcium oxide, and zeolite decreased the $\mathrm{Cu}$ content of the aerial biomass of maize by $22-31 \%$ on average relative to the control treatment (without soil amendments). Soil amendments significantly modified $\mathrm{Zn}$ concentration in the aboveground parts of spring barley (main crop) and maize (successive crop) (Table 5). In treatments contaminated with $\mathrm{Cr}(\mathrm{III})$, the average $\mathrm{Zn}$ content of the aboveground parts of spring barley was most significantly increased by zeolite and compost relative to the control treatment (without soil amendments). The analyzed amendments were less effective in $\mathrm{Cr}(\mathrm{VI})$ treatments. In pots contaminated with $\mathrm{Cr}(\mathrm{III})$ and $\mathrm{Cr}(\mathrm{VI})$, calcium oxide and zeolite caused the greatest decrease in the average $\mathrm{Zn}$ content of maize (successive crop). However, the tested amendments exerted the greatest effect on the $\mathrm{Zn}$ content of maize contaminated with $\mathrm{Cr}(\mathrm{VI})$. Compost, zeolite, and calcium oxide had a significant influence on the $\mathrm{Ni}$ content of the aboveground parts of the tested crops (Table 5). The accumulation of $\mathrm{Ni}$ in the aerial biomass of spring barley was most significantly determined by compost $(+36 \%$ on average) in $\mathrm{Cr}$ (III) treatments and by zeolite $(+306 \%)$ and calcium oxide $(+242 \%)$ in $\mathrm{Cr}(\mathrm{VI})$ treatments. In pots contaminated with $\mathrm{Cr}(\mathrm{VI})$, the high increase in Ni concentration under exposure to zeolite and calcium oxide can be attributed to the fact that average values were calculated only for pots with low doses of $\mathrm{Cr}(\mathrm{VI})$ due to the low availability of biomass samples from more contaminated treatments, which prevented the determination of $\mathrm{Ni}$ content. Compost enhanced the accumulation of $\mathrm{Ni}$ in spring barley in $\mathrm{Cr}(\mathrm{VI})$ treatments, whereas zeolite and, in 
Table 5 Effect of chromium contamination and soil amendments on heavy-metal content in spring barley (Hordeum vulgare L.) and maize (Zea mays L.), $\mathrm{mg} \mathrm{kg}^{-1}$

$\mathrm{Cr}$ dose in $\mathrm{mg} \mathrm{kg}^{-1}$ of soil Kind of contamination

\begin{tabular}{|c|c|c|c|c|c|c|c|}
\hline $\mathrm{Cr}(\mathrm{III})$ & $\mathrm{Cr}(\mathrm{VI})$ & $\mathrm{Cr}(\mathrm{III})$ & $\mathrm{Cr}(\mathrm{VI})$ & $\mathrm{Cr}(\mathrm{III})$ & $\mathrm{Cr}(\mathrm{VI})$ & $\mathrm{Cr}(\mathrm{III})$ & $\mathrm{Cr}(\mathrm{VI})$ \\
\hline \multicolumn{8}{|c|}{ Kind of soil amendments } \\
\hline $\begin{array}{l}\text { Without soil } \\
\text { amendments }\end{array}$ & $\begin{array}{l}\text { Without soil } \\
\text { amendments }\end{array}$ & Compost & Compost & Zeolite & Zeolite & $\begin{array}{l}\text { Calcium } \\
\text { oxide }\end{array}$ & $\begin{array}{l}\text { Calcium } \\
\text { oxide }\end{array}$ \\
\hline
\end{tabular}

Content of $\mathrm{Cr}\left(\mathrm{mg} \mathrm{kg}^{-1}\right)$

Barley (Hordeum vulgare L.) - main crop

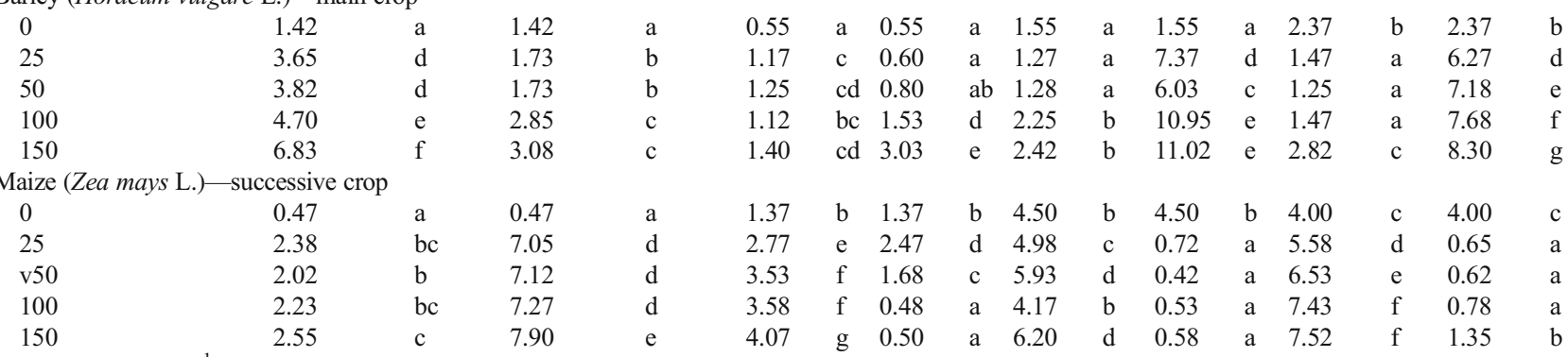

Content of $\mathrm{Cu}\left(\mathrm{mg} \mathrm{kg}^{-1}\right)$

Barley (Hordeum vulgare L.) -main crop

$\begin{array}{llll}0 & 2.82 & \text { a } & 2.82\end{array}$

$\begin{array}{llll}25 & 2.97 & \text { ab } & 4.63 \\ 50 & 3.30 & \text { b } & 5.78\end{array}$

$\begin{array}{llll}100 & 3.93 & \text { c } & 5.48\end{array}$

150

$7.93 \quad \mathrm{f} \quad 3.92$

2.82

63

3.92

Maize (Zea mays L.) - successive crop

0

25

50

100

150

10.05

15.38

17.87

17.27

12.15

a
e
g
f
b

10.05

14.43

12.13

13.82

13.67

Content of $\mathrm{Zn}\left(\mathrm{mg} \mathrm{kg}^{-1}\right)$

Barley (Hordeum vulgare L.) -main crop

$0 \quad 128.90$

$\begin{array}{llll}0 & 128.90 & f & 128.90\end{array}$

25

50

100

104.30

89.30

$73.60 \quad a b$

150

72.30

Maize (Zea mays L.)- successive crop

0

25

50

100

150

$82.30 \quad \mathrm{e}$

60.60

69.50

67.50

54.30

Content of $\mathrm{Ni}\left(\mathrm{mg} \mathrm{kg}^{-1}\right)$

Barley (Hordeum vulgare L.) - main crop

\begin{tabular}{|c|c|c|c|c|c|c|c|c|c|c|c|c|c|c|c|c|}
\hline & & & & & & & & & & & & & & & & \\
\hline 0 & 128.90 & $\mathrm{f}$ & 128.90 & $\mathrm{f}$ & 125.90 & $\mathrm{e}$ & 125.90 & $\mathrm{e}$ & 124.00 & $\mathrm{f}$ & 124.00 & $\mathrm{f}$ & 108.20 & $\mathrm{e}$ & 108.20 & e \\
\hline 25 & 104.30 & $\mathrm{e}$ & 85.60 & $\mathrm{~cd}$ & 114.10 & $\mathrm{~d}$ & 93.20 & b & 121.00 & def & 88.00 & $\mathrm{c}$ & 99.40 & $\mathrm{~d}$ & 77.80 & $\mathrm{~b}$ \\
\hline 50 & 89.30 & d & 80.00 & $\mathrm{bc}$ & 120.30 & de & 69.50 & $\mathrm{a}$ & 122.50 & ef & 67.70 & $\mathrm{a}$ & 95.80 & $\mathrm{~cd}$ & 74.50 & $\mathrm{~b}$ \\
\hline 100 & 73.60 & $a b$ & 72.60 & $\mathrm{a}$ & 102.10 & $\mathrm{c}$ & 65.20 & $\mathrm{a}$ & 115.50 & d & 72.50 & $a b$ & 89.80 & $\mathrm{c}$ & 65.30 & $\mathrm{a}$ \\
\hline 150 & 72.30 & $\mathrm{a}$ & 70.20 & $\mathrm{a}$ & 87.90 & $\mathrm{~b}$ & 63.40 & $\mathrm{a}$ & 116.80 & de & 75.05 & $\mathrm{~b}$ & 75.90 & $\mathrm{~b}$ & 69.60 & $a b$ \\
\hline Maize & cessive & & & & & & & & & & & & & & & \\
\hline 0 & 82.30 & e & 82.30 & e & 57.90 & $\mathrm{~d}$ & 57.90 & d & 41.80 & $\mathrm{~d}$ & 41.80 & $\mathrm{~d}$ & 27.60 & $\mathrm{c}$ & 27.60 & $\mathrm{c}$ \\
\hline 25 & 60.60 & $\mathrm{c}$ & 49.20 & $\mathrm{a}$ & 48.20 & $\mathrm{~b}$ & 42.40 & $\mathrm{a}$ & 42.90 & $\mathrm{~d}$ & 7.50 & $\mathrm{a}$ & 30.30 & d & 9.10 & $\mathrm{~b}$ \\
\hline 50 & 69.50 & $\mathrm{~d}$ & 47.20 & $\mathrm{a}$ & 48.20 & $\mathrm{~b}$ & 53.30 & $\mathrm{c}$ & 44.30 & $\mathrm{~d}$ & 10.80 & $a b$ & 40.60 & d & 5.00 & $\mathrm{a}$ \\
\hline 100 & 67.50 & d & 47.60 & $\mathrm{a}$ & 48.90 & $\mathrm{~b}$ & 68.20 & $\mathrm{e}$ & 48.60 & $\mathrm{e}$ & 11.60 & $\mathrm{bc}$ & 51.60 & $\mathrm{f}$ & 4.00 & $\mathrm{a}$ \\
\hline 150 & 54.30 & $\mathrm{~b}$ & 47.10 & $\mathrm{a}$ & 50.80 & bc & 99.50 & $\mathrm{f}$ & 69.30 & $\mathrm{f}$ & 14.50 & $\mathrm{c}$ & 51.40 & $\mathrm{f}$ & 2.70 & $\mathrm{a}$ \\
\hline ontent $\mathrm{o}$ & & & & & & & & & & & & & & & & \\
\hline Barley & L.) $-m a$ & & & & & & & & & & & & & & & \\
\hline 0 & 20.30 & e & 20.30 & $\mathrm{e}$ & 19.72 & $\mathrm{~g}$ & 19.72 & $\mathrm{~g}$ & 14.23 & $\mathrm{~d}$ & 14.23 & $\mathrm{~d}$ & 17.95 & $\mathrm{c}$ & 17.95 & $\mathrm{c}$ \\
\hline 25 & 9.60 & $\mathrm{~d}$ & 6.03 & $\mathrm{c}$ & 15.18 & f & 5.00 & $\mathrm{a}$ & 9.37 & $\mathrm{bc}$ & 41.27 & $\mathrm{f}$ & 3.43 & $\mathrm{~b}$ & 23.58 & $\mathrm{~d}$ \\
\hline 50 & 9.27 & $\mathrm{~d}$ & 3.98 & $\mathrm{~b}$ & 15.78 & $\mathrm{f}$ & 4.53 & $\mathrm{a}$ & 11.37 & $\mathrm{~cd}$ & 25.90 & e & 1.92 & $\mathrm{a}$ & 28.17 & $\mathrm{f}$ \\
\hline 100 & 8.68 & d & 2.30 & $\mathrm{a}$ & 12.18 & e & 6.82 & b & 7.10 & $a b$ & 28.80 & e & 1.68 & $\mathrm{a}$ & 25.6 & $\mathrm{e}$ \\
\hline 150 & 6.43 & c & 1.33 & $\mathrm{a}$ & 10.97 & $\mathrm{~d}$ & 8.95 & c & 5.18 & $\mathrm{a}$ & 26.5 & e & 1.45 & $\mathrm{a}$ & 26.3 & e \\
\hline Maize & cessive & & & & & & & & & & & & & & & \\
\hline 0 & 61.43 & f & 61.43 & $\mathrm{f}$ & 5.50 & $\mathrm{~b}$ & 5.50 & b & 4.07 & $\mathrm{c}$ & 4.07 & c & 2.10 & $\mathrm{bc}$ & 2.10 & bc \\
\hline 25 & 16.33 & $\mathrm{e}$ & 5.17 & $\mathrm{c}$ & 25.55 & f & 5.58 & b & 1.17 & $\mathrm{a}$ & 6.63 & $\mathrm{f}$ & 1.70 & $\mathrm{a}$ & 4.15 & $\mathrm{~g}$ \\
\hline 50 & 13.80 & $\mathrm{~d}$ & 1.37 & $\mathrm{a}$ & 14.87 & $\mathrm{e}$ & 2.47 & $\mathrm{a}$ & 1.17 & $\mathrm{a}$ & 5.37 & e & 2.22 & $\mathrm{c}$ & 3.20 & $\mathrm{e}$ \\
\hline 100 & 4.45 & $\mathrm{bc}$ & 3.13 & $a b c$ & 11.53 & $\mathrm{~d}$ & 2.13 & $\mathrm{a}$ & 1.23 & $\mathrm{a}$ & 5.03 & $\mathrm{~d}$ & 1.93 & $a b$ & 2.50 & $\mathrm{~d}$ \\
\hline 150 & 1.27 & $\mathrm{a}$ & 2.40 & $\mathrm{ab}$ & 7.90 & c & 2.17 & $\mathrm{a}$ & 1.20 & $\mathrm{a}$ & 3.37 & $\mathrm{~b}$ & 3.10 & e & 3.63 & $\mathrm{f}$ \\
\hline
\end{tabular}

Different letters indicate significant difference at $p<0.05$

$\begin{array}{llllllllllll}5.03 & \mathrm{a} & 5.03 & \mathrm{a} & 2.10 & \mathrm{bc} & 2.10 & \mathrm{bc} & 2.23 & \mathrm{a} & 2.23 & \mathrm{a} \\ 5.35 & \mathrm{ab} & 5.58 & \mathrm{ab} & 0.63 & \mathrm{a} & 12.82 & \mathrm{~d} & 5.17 & \mathrm{c} & 12.93 & \mathrm{~g} \\ 5.35 & \mathrm{ab} & 12.58 & \mathrm{~d} & 0.98 & \mathrm{a} & 14.90 & \mathrm{e} & 5.57 & \mathrm{~cd} & 12.03 & \mathrm{e} \\ 6.05 & \mathrm{~b} & 12.45 & \mathrm{~d} & 1.88 & \mathrm{~b} & 14.92 & \mathrm{e} & 5.37 & \mathrm{~d} & 12.50 & \mathrm{f} \\ 8.38 & \mathrm{c} & 14.80 & \mathrm{e} & 2.63 & \mathrm{c} & 15.20 & \mathrm{e} & 4.53 & \mathrm{~b} & 12.88 & \mathrm{~g} \\ & & & & & & & & & & & \\ 12.03 & \mathrm{c} & 12.03 & \mathrm{c} & 14.23 & \mathrm{c} & 14.23 & \mathrm{c} & 11.63 & \mathrm{c} & 11.63 & \mathrm{c} \\ 11.32 & \mathrm{bc} & 12.20 & \mathrm{c} & 16.80 & \mathrm{f} & 7.97 & \mathrm{~b} & 13.15 & \mathrm{~d} & 10.10 & \mathrm{~b} \\ 19.55 & \mathrm{f} & 10.32 & \mathrm{~b} & 16.05 & \mathrm{e} & 7.07 & \mathrm{a} & 14.80 & \mathrm{e} & 8.87 & \mathrm{a} \\ 16.70 & \mathrm{e} & 6.83 & \mathrm{a} & 15.45 & \mathrm{~d} & 7.20 & \mathrm{a} & 16.35 & \mathrm{f} & 9.70 & \mathrm{ab} \\ 13.97 & \mathrm{~d} & 7.68 & \mathrm{a} & 14.52 & \mathrm{c} & 7.77 & \mathrm{~b} & 14.57 & \mathrm{e} & 9.87 & \mathrm{ab}\end{array}$


particular, calcium oxide decreased the $\mathrm{Ni}$ content of spring barley in $\mathrm{Cr}(\mathrm{III})$ treatments. In treatments contaminated with $\mathrm{Cr}(\mathrm{III})$ and $\mathrm{Cr}(\mathrm{VI})$, all soil amendments decreased the $\mathrm{Ni}$ content of the aerial biomass of maize (successive crop) relative to the control treatment (without soil amendments). In pots with $\mathrm{Cr}(\mathrm{III})$, the greatest decrease in the Ni content of maize was induced by zeolite and calcium oxide at $91 \%$ and $89 \%$, respectively, whereas compost and calcium oxide decreased $\mathrm{Ni}$ concentration in maize by $76 \%$ and $79 \%$, respectively, in $\mathrm{Cr}(\mathrm{VI})$ treatments.

\section{The effect of $\mathrm{Cr}(\mathrm{III}), \mathrm{Cr}(\mathrm{VI})$, and soil amendments on soil pH}

Contamination with $\mathrm{Cr}(\mathrm{III})$ and $\mathrm{Cr}(\mathrm{VI})$ significantly affected soil pH (Fig. 3). In treatments without soil amendments, small doses of $\mathrm{Cr}(\mathrm{III})$ and $\mathrm{Cr}(\mathrm{VI})$ soil (up to $50 \mathrm{mg} \mathrm{kg}^{-1}$ ) caused a gradual increase in soil $\mathrm{pH}$, whereas higher $\mathrm{Cr}$ doses decreased the analyzed parameter. Soil contaminated with $\mathrm{Cr}$ (III) was characterized by slightly higher $\mathrm{pH}$ values. All of the evaluated soil amendments significantly influenced soil $\mathrm{pH}$ in spring barley and maize treatments contaminated with both $\mathrm{Cr}(\mathrm{III})$ and $\mathrm{Cr}(\mathrm{VI})$. Calcium oxide was most effective, and it induced a significant increase in soil $\mathrm{pH}$ relative to the control treatment. Zeolite and compost contributed to only a minor improvement in soil $\mathrm{pH}$ in treatments contaminated with $\mathrm{Cr}(\mathrm{III})$.

The effect of $\mathrm{Cr}(\mathrm{III})$ and $\mathrm{Cr}(\mathrm{VI})$ contamination on the heavy-metal content of soil

The average $\mathrm{Cr}$ content of soil was $4 \%$ higher in $\mathrm{Cr}(\mathrm{VI})$ treatments where spring barley and maize were grown without soil amendments (Table 6). In these pots, the highest $\mathrm{Cr}(\mathrm{VI})$ dose of $150 \mathrm{mg} \mathrm{kg}^{-1}$ soil induced an 11-fold increase in the $\mathrm{Cr}$ content of soil. A somewhat smaller, 10-fold increase was observed in $\mathrm{Cr}$ (III) treatments relative to the control treatment.
After harvest, the average $\mathrm{Cu}$ content of soil was significantly higher in non-amended treatments exposed to $\mathrm{Cr}$ (III). In the control treatment (without amendments), a negative correlation was observed between increasing doses of $\mathrm{Cr}$ (III)and $\mathrm{Cr}(\mathrm{VI})$ and the $\mathrm{Cu}$ content of soil, where $\mathrm{Cr}(\mathrm{VI})$ exerted a far stronger effect. After harvest in non-amended treatments, the accumulation of $\mathrm{Zn}$ in soil was negatively correlated with increasing doses of $\mathrm{Cr}(\mathrm{III})$ and $\mathrm{Cr}(\mathrm{VI})$. In these treatments, the concentration of $\mathrm{Zn}$ was lowest in response to $\mathrm{Cr}$ (III) doses of 100 and $150 \mathrm{mg} \mathrm{kg}^{-1}$ soil. The $\mathrm{Zn}$ content of control soil was more than $10 \%$ lower. The average Ni content of soil in nonamended treatments after harvest was similar in pots contaminated with $\mathrm{Cr}(\mathrm{III})$ and $\mathrm{Cr}(\mathrm{VI})$. In these treatments, the concentration of $\mathrm{Ni}$ was negatively correlated with increasing doses of $\mathrm{Cr}(\mathrm{III})$ and $\mathrm{Cr}(\mathrm{VI})$, where $\mathrm{Cr}(\mathrm{VI})$ exerted a stronger effect on the studied parameter. However, the observed changes did not exceed several percent.

\section{The effect of soil amendments on the heavy-metal content of soil}

In pots sown with spring barley and maize, all of the tested soil amendments decreased the average $\mathrm{Cr}$ content of soil in all experimental variants (Table 6). In treatments contaminated with $\mathrm{Cr}(\mathrm{III})$ and $\mathrm{Cr}(\mathrm{VI})$, the concentration of $\mathrm{Cr}$ was most effectively reduced by zeolite at $9 \%$ and $8 \%$, respectively, relative to the control treatment. The $\mathrm{Cu}$ content of soil after harvest was reduced by all of the evaluated amendments in treatments contaminated with both $\mathrm{Cr}(\mathrm{III})$ and $\mathrm{Cr}(\mathrm{VI})$. Calcium oxide was most effective, and it decreased the concentration of $\mathrm{Cu}$ by $24 \%$ and $14 \%$, respectively, relative to the control treatment (without soil amendments). The addition of compost increased the average $\mathrm{Zn}$ content of soil by $21 \%$ in $\mathrm{Cr}(\mathrm{III})$ treatments and by $5 \%$ in $\mathrm{Cr}(\mathrm{VI})$ treatments relative to the control treatment (without soil amendments). Calcium oxide had a weaker influence on $\mathrm{Cr}(\mathrm{III})$ and $\mathrm{Cr}(\mathrm{VI})$ treatments,

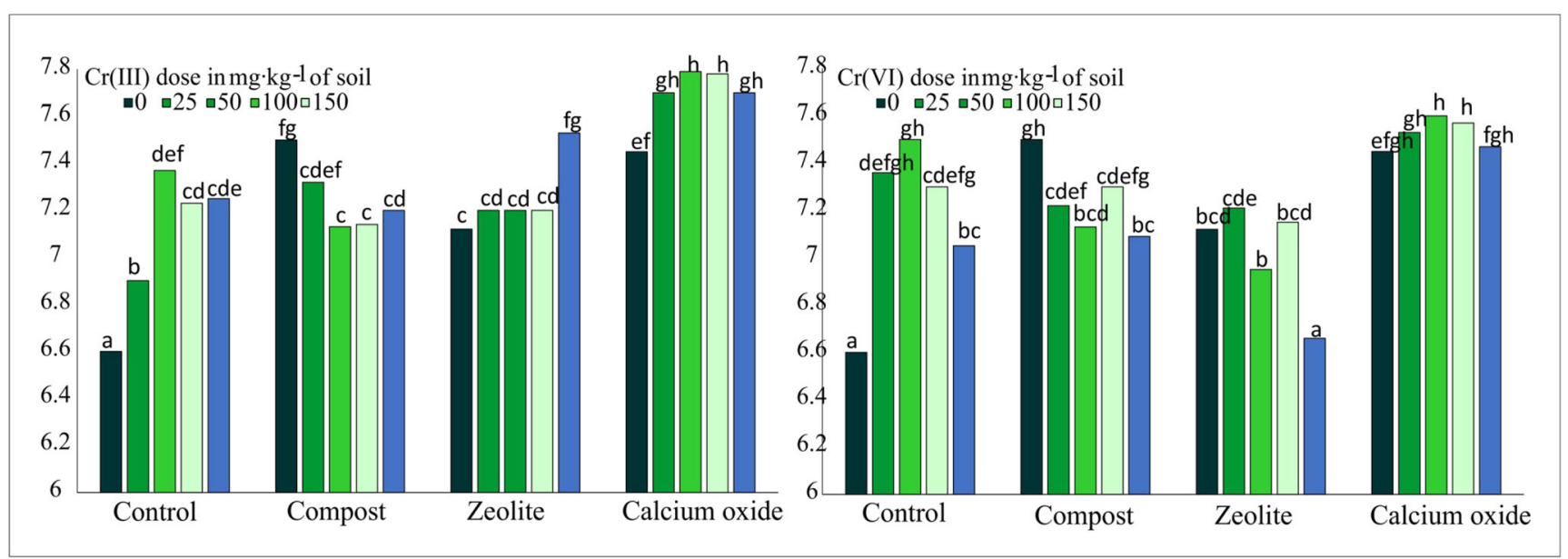

Fig. 3 The $\mathrm{pH}$ value of soil in pots contaminated with different doses of $\mathrm{Cr}(\mathrm{III})$ and $\mathrm{Cr}(\mathrm{VI})\left(0 ; 25 ; 50 ; 150 \mathrm{mg} \mathrm{kg}^{-1}\right.$ soil $)$ and soil amendments. Different letters above the columns indicated significant difference at the $p<0.05$ 
Table 6 Content of heavy metals in soil $\left(\mathrm{mg} \mathrm{kg}^{-1}\right)$

$\mathrm{Cr}$ dose in $\mathrm{m} \mathrm{kg}^{-1}$ of soil Kind of contamination

\begin{tabular}{|c|c|c|c|c|c|c|c|}
\hline $\mathrm{Cr}(\mathrm{III})$ & $\mathrm{Cr}(\mathrm{VI})$ & $\mathrm{Cr}(\mathrm{III})$ & $\mathrm{Cr}(\mathrm{VI})$ & $\mathrm{Cr}(\mathrm{III})$ & $\mathrm{Cr}(\mathrm{VI})$ & $\mathrm{Cr}(\mathrm{III})$ & $\mathrm{Cr}(\mathrm{VI})$ \\
\hline \multicolumn{8}{|c|}{ Kind of soil amendments } \\
\hline $\begin{array}{l}\text { Without soil } \\
\text { amendments }\end{array}$ & $\begin{array}{l}\text { Without soil } \\
\text { amendments }\end{array}$ & Compost & Compost & Zeolite & Zeolite & $\begin{array}{l}\text { Calcium } \\
\text { oxide }\end{array}$ & $\begin{array}{l}\text { Calcium } \\
\text { oxide }\end{array}$ \\
\hline
\end{tabular}

\begin{tabular}{|c|c|c|c|c|c|c|c|c|c|c|c|c|c|c|c|c|}
\hline \multicolumn{17}{|c|}{ Content of $\mathrm{Cr}\left(\mathrm{mg} \mathrm{kg}^{-1}\right)$} \\
\hline 0 & 13.18 & $\mathrm{a}$ & 13.18 & $\mathrm{a}$ & 14.65 & $\mathrm{a}$ & 14.65 & $\mathrm{a}$ & 11.85 & $\mathrm{a}$ & 11.85 & $\mathrm{a}$ & 11.45 & $\mathrm{a}$ & 11.45 & $\mathrm{a}$ \\
\hline 25 & 24.67 & $\mathrm{c}$ & 18.30 & $\mathrm{~b}$ & 24.14 & $\mathrm{c}$ & 19.05 & $\mathrm{~b}$ & 18.65 & $\mathrm{~b}$ & 17.15 & $\mathrm{~b}$ & 18.20 & $\mathrm{~b}$ & 19.00 & $\mathrm{~b}$ \\
\hline 50 & 45.56 & $\mathrm{~d}$ & 48.15 & $\mathrm{~d}$ & 47.65 & $\mathrm{~d}$ & 45.45 & $\mathrm{~d}$ & 48.40 & $\mathrm{c}$ & 48.15 & $\mathrm{c}$ & 47.80 & $\mathrm{~d}$ & 41.40 & $\mathrm{c}$ \\
\hline 100 & 95.47 & $\mathrm{e}$ & 97.90 & e & 90.45 & $\mathrm{e}$ & 94.35 & $\mathrm{e}$ & 81.40 & $\mathrm{~d}$ & 86.50 & $\mathrm{e}$ & 90.20 & $\mathrm{e}$ & 88.45 & $\mathrm{e}$ \\
\hline 150 & 133.22 & $\mathrm{f}$ & 147.36 & $\mathrm{~g}$ & 128.35 & $\mathrm{f}$ & 146.90 & $\mathrm{~g}$ & 124.10 & $\mathrm{f}$ & 132.85 & $\mathrm{~g}$ & 143.20 & $\mathrm{f}$ & 146.95 & $\mathrm{f}$ \\
\hline \multicolumn{17}{|c|}{ Content of $\mathrm{Cu}\left(\mathrm{mg} \mathrm{kg}^{-1}\right)$} \\
\hline 0 & 24.67 & de & 24.67 & de & 24.06 & $\mathrm{~g}$ & 24.06 & $\mathrm{~g}$ & 20.10 & $\mathrm{a}$ & 20.10 & $\mathrm{a}$ & 19.59 & $\mathrm{f}$ & 19.59 & $\mathrm{f}$ \\
\hline 25 & 24.91 & $\mathrm{e}$ & 18.69 & $\mathrm{~b}$ & 23.86 & ef & 18.47 & $\mathrm{c}$ & 19.56 & $\mathrm{a}$ & 17.64 & $\mathrm{a}$ & 18.38 & $\mathrm{e}$ & 16.68 & $\mathrm{c}$ \\
\hline 50 & 24.85 & $\mathrm{e}$ & 18.49 & $\mathrm{~b}$ & 23.45 & def & 17.71 & $\mathrm{bc}$ & 18.57 & a & 16.83 & $\mathrm{a}$ & 18.17 & de & 16.25 & $\mathrm{bc}$ \\
\hline 100 & 23.30 & $\mathrm{~d}$ & 17.43 & $a b$ & 22.95 & de & 17.12 & $a b$ & 18.27 & $\mathrm{a}$ & 16.88 & $\mathrm{a}$ & 17.65 & $\mathrm{~d}$ & 15.65 & $\mathrm{~b}$ \\
\hline 150 & 21.71 & $\mathrm{c}$ & 16.77 & $\mathrm{a}$ & 22.60 & $\mathrm{~d}$ & 16.73 & $\mathrm{a}$ & 17.71 & $\mathrm{a}$ & 16.02 & $\mathrm{a}$ & 16.85 & $\mathrm{c}$ & 14.91 & $\mathrm{a}$ \\
\hline \multicolumn{17}{|c|}{ Content of $\mathrm{Zn}\left(\mathrm{mg} \mathrm{kg}^{-1}\right)$} \\
\hline 0 & 43.42 & $\mathrm{c}$ & 43.42 & $\mathrm{c}$ & 54.39 & $\mathrm{f}$ & 54.39 & $\mathrm{f}$ & 42.57 & d & 42.57 & d & 41.73 & $\mathrm{e}$ & 41.73 & $\mathrm{e}$ \\
\hline 25 & 40.16 & $\mathrm{~b}$ & 42.42 & $\mathrm{c}$ & 45.27 & d & 42.36 & $\mathrm{c}$ & 39.87 & $\mathrm{~b}$ & 38.33 & $\mathrm{a}$ & 40.99 & de & 39.76 & $\mathrm{~cd}$ \\
\hline 50 & 38.24 & $\mathrm{ab}$ & 43.21 & $\mathrm{c}$ & 39.13 & $\mathrm{ab}$ & 41.85 & bc & 41.26 & $\mathrm{c}$ & 38.34 & $\mathrm{a}$ & 43.72 & $\mathrm{f}$ & 38.37 & $\mathrm{c}$ \\
\hline 100 & 36.33 & $\mathrm{a}$ & 39.49 & $\mathrm{~b}$ & 46.88 & $\mathrm{~d}$ & 39.55 & $a b c$ & 40.27 & $\mathrm{bc}$ & 39.69 & $\mathrm{~b}$ & 43.87 & $\mathrm{f}$ & 34.74 & $\mathrm{~b}$ \\
\hline 150 & 36.47 & $\mathrm{a}$ & 38.25 & $\mathrm{ab}$ & 49.82 & $\mathrm{e}$ & 38.24 & $\mathrm{a}$ & 40.32 & $\mathrm{bc}$ & 39.61 & $a b$ & 45.02 & $\mathrm{f}$ & 30.75 & $\mathrm{a}$ \\
\hline \multicolumn{17}{|c|}{ Content of $\mathrm{Ni}\left(\mathrm{mg} \mathrm{kg}^{-1}\right)$} \\
\hline 0 & 5.74 & $\mathrm{e}$ & 5.74 & $\mathrm{e}$ & 3.32 & $\mathrm{~b}$ & 3.32 & $\mathrm{~b}$ & 3.38 & $\mathrm{ab}$ & 3.38 & $\mathrm{ab}$ & 2.56 & $\mathrm{~b}$ & 2.56 & $\mathrm{~b}$ \\
\hline 25 & 5.56 & $\mathrm{e}$ & 4.60 & $\mathrm{~d}$ & 2.88 & $\mathrm{a}$ & 2.65 & $\mathrm{a}$ & 3.65 & $\mathrm{bc}$ & 3.89 & de & 2.65 & $\mathrm{~b}$ & 3.34 & $\mathrm{~d}$ \\
\hline 50 & 4.47 & $\mathrm{~d}$ & 3.76 & $\mathrm{bc}$ & 2.83 & $\mathrm{a}$ & 2.65 & a & 3.12 & $\mathrm{a}$ & 4.06 & de & 2.67 & $\mathrm{~b}$ & 3.04 & $\mathrm{c}$ \\
\hline 100 & 4.20 & $\mathrm{~cd}$ & 3.43 & $\mathrm{ab}$ & 2.83 & $\mathrm{a}$ & 3.27 & $\mathrm{~b}$ & 3.63 & $\mathrm{bc}$ & 4.21 & $\mathrm{e}$ & 2.73 & $\mathrm{~b}$ & 2.76 & $\mathrm{~b}$ \\
\hline 150 & 4.10 & $\mathrm{~cd}$ & 3.02 & $\mathrm{a}$ & 2.75 & $\mathrm{a}$ & 3.93 & $\mathrm{c}$ & 4.06 & de & 5.11 & $\mathrm{f}$ & 3.23 & $\mathrm{~cd}$ & 2.18 & $\mathrm{a}$ \\
\hline
\end{tabular}

Different letters indicate significant difference at the $p<0.05$

and it exerted opposite effects on pots with $\mathrm{Cr}$ (III) and $\mathrm{Cr}(\mathrm{VI})$. All of the tested soil amendments negatively affected the average Ni content of soil in $\mathrm{Cr}$ (III) and $\mathrm{Cr}(\mathrm{VI})$ treatments after harvest. Calcium oxide and compost decreased the concentration of $\mathrm{Ni}$ by $43 \%$ and $39 \%$, respectively, in $\mathrm{Cr}$ (III) treatments, and by $33 \%$ and $23 \%$, respectively, in $\mathrm{Cr}(\mathrm{VI})$ treatments, relative to the control treatment (without soil amendments).

\section{Discussion}

The results of the present study and literature data published in recent years (Wyszkowski and Radziemska 2009; Paul et al. 2015; Saleem et al. 2015; Molla et al. 2017) indicate that $\mathrm{Cr}$ (III) and $\mathrm{Cr}(\mathrm{VI})$ compounds exert a negative effect on the natural environment, including soil and plants. Heavy metals accumulated in soil, including $\mathrm{Cr}$, are easily transported to the aerial parts of plants, and they exert long-term effects on biotic components in ecosystems (Radziemska et al. 2017a). Assisted remediation decreases the availability of heavy metals and promotes the growth of permanent vegetative cover on contaminated land. In the presented study, spring barley (main crop) grown without soil amendments was highly sensitive to soil contamination with $\mathrm{Cr}(\mathrm{VI})$. In contrast, maize (successive crop) yields improved under exposure to increasing doses of $\mathrm{Cr}$ (III) and $\mathrm{Cr}(\mathrm{VI})$. Hexavalent chromium compounds are toxic for plants. When applied in identical doses, $\mathrm{Cr}_{2} \mathrm{O}_{7}{ }^{2-}$ is strongly toxic, whereas $\mathrm{Cr}$ (III) does not cause plant damage. Sensitive plants exhibit symptoms of toxicity already under exposure to a $\mathrm{Cr}(\mathrm{VI})$ dose of $1-2 \mathrm{mg} \mathrm{kg}^{-1}$ soil (Shahid et al. 2017). The changes observed in plants, such as reduced biomass yield, are indicative of the toxic effects of $\mathrm{Cr}$ compounds (Patra et al. 2018). Plants control heavy-metal concentrations by inhibiting their root uptake and transfer to tissues 
or by immobilizing contaminants through the formation of bonds with biologically active molecules (Hedayatkhaha et al. 2018).

In this study, the $\mathrm{Cr}$ content of the aerial parts of the tested plants increased with a rise in heavy-metal concentrations in soil. Our results are consistent with previous findings (Wyszkowski and Radziemska 2009, 2013; Sinha et al. 2018). The average concentrations of $\mathrm{Cr}, \mathrm{Zn}$, and $\mathrm{Ni}$ were higher in the aerial biomass of spring barley and maize exposed to $\mathrm{Cr}$ (III) than $\mathrm{Cr}(\mathrm{VI})$. Soil amendments that promote the mobilization or immobilization of soil contaminants play a key role in the process of removing or immobilizing $\mathrm{Cr}$ in soil and improving soil quality (Hamid et al. 2019). In a study by Antoniadis et al. (2018), the total content of $\mathrm{Cr}$ (III) and $\mathrm{Cr}$ (IV) in the aerial biomass of oregano reached $404.27 \mathrm{mg} \mathrm{kg}^{-1} \mathrm{DM}$ in untreated soil and $423.33 \mathrm{mg} \mathrm{kg}^{-1} \mathrm{DM}$ in soil treated with zeolite. Heavy metals can cause various changes in the soil ecosystem (Chu et al. 2018), and anthropogenic factors, including $\mathrm{Cr}$ contamination, significantly modify the physical, chemical, and biological properties of soil (Dotaniya et al. 2017). Soil parameters, in particular $\mathrm{pH}$, granulometric composition, and the content of humic substances, significantly influence the oxidation of $\mathrm{Cr}$ compounds (He et al. 2018) and their toxic effects on plants. The leaching of base compounds from soil increased solubility of $\mathrm{Mn}$ and $\mathrm{Al}$ compounds and other phytotoxic substances, and a decrease in nutrient availability also altered the chemical properties of soil (Lee et al. 2019). Soil $\mathrm{pH}$ and organic matter content are the key determinants of the bioavailability of heavy metals and their effect on plants (Liu et al. 2019). The valence state and sorption of $\mathrm{Cr}$ in soil are affected by soil $\mathrm{pH}$ and redox potential. In soils with a $\mathrm{pH}$ of $5.5, \mathrm{Cr}$ (III) cations are precipitated from the solution and, unlike $\mathrm{Cr}(\mathrm{VI})$ cations, are sparingly soluble. Cr(III) sorption increases, whereas $\mathrm{Cr}$ (VI) sorption decreases with a rise in soil acidity (Elouahli et al. 2018). In the present experiment, calcium oxide led to the greatest increase in soil $\mathrm{pH}$ relative to the control treatment. Zeolite and compost induced a smaller increase in soil $\mathrm{pH}$ in $\mathrm{Cr}$ (III) treatments.

Calcium oxide and, partly, zeolite also decreased the $\mathrm{Cu}$ and Ni content of soil. The results of this study and other authors' findings indicate that zeolites effectively remove heavy metals, including $\mathrm{Cr}$, from soil due to their high porosity and sorptive capacity (Antoniadis et al. 2018; Feng et al. 2018; Huang and Wei 2018). Eyvazi et al. (2019) found that nano-magnetic $\mathrm{MnFe}_{2} \mathrm{O}_{4}$ significantly enhanced the immobilization of $\mathrm{Cr}(\mathrm{VI})$ by decreasing leachability, plant bioavailability, human bioaccessibility, and risk of release. In comparison with other heavy metals, $\mathrm{Cr}$ is most strongly bound to soil organic matter (Hseu et al. 2018), which is why compost is an effective soil amendment (Adejumo et al. 2018; Goswami et al. 2018). In a greenhouse experiment conducted by Chen et al. (2018), compost decreased the availability of Cr by making it more stable and less mobile. Similar observations were made in this study, where the application of compost decreased the $\mathrm{Cr}$ content of soil in both experimental variants. In the presence of organic matter containing humic substances, $\mathrm{Cr}^{3+}$ ions are bound with or absorbed by surfaceactive organic and mineral compounds (Yin et al. 2018).

\section{Conclusions}

Soil contamination with $\mathrm{Cr}$ is a major environmental and health concern. Spring barley (main crop) was highly sensitive to soil contamination with $\mathrm{Cr}(\mathrm{VI})$, whereas the biomass yield of maize (successive crop) increased with a rise in $\mathrm{Cr}$ (III) and $\mathrm{Cr}(\mathrm{VI})$ doses. The tested soil amendments increased the average yield of the aerial biomass of maize only in pots contaminated with $\mathrm{Cr}(\mathrm{III})$. In non-amended treatments, the average $\mathrm{Cr}, \mathrm{Zn}$, and $\mathrm{Ni}$ content of the aboveground parts of spring barley and maize was higher in pots with $\mathrm{Cr}$ (III) than in $\mathrm{Cr}(\mathrm{VI})$ treatments. The $\mathrm{Cr}$ content of maize was 3 times higher in $\mathrm{Cr}(\mathrm{VI})$ treatments than in $\mathrm{Cr}(\mathrm{III})$ treatments. The average concentration of $\mathrm{Cu}$ was higher in the aerial biomass of spring barley exposed to $\mathrm{Cr}(\mathrm{VI})$ than in that exposed to $\mathrm{Cr}$ (III). Calcium oxide significantly increased soil $\mathrm{pH}$ relative to the control treatment. In non-amended treatments, the average $\mathrm{Cr}$ content of soil was higher in $\mathrm{Cr}(\mathrm{VI})$ treatments. In these pots, the concentration of $\mathrm{Cr}$ increased 11-fold under exposure to the $\mathrm{Cr}(\mathrm{VI})$ dose of $150 \mathrm{mg} \mathrm{kg}^{-1}$ soil. In non-amended treatments, the accumulation of $\mathrm{Zn}$ and $\mathrm{Cn}$ was negatively correlated with increasing doses of $\mathrm{Cr}$ (III) and $\mathrm{Cr}$ (VI). Calcium oxide decreased the average content of $\mathrm{Cr}, \mathrm{Cu}$, and $\mathrm{Ni}$ in all experimental variants. The application of compost increased the average concentration of $\mathrm{Zn}$ in pots contaminated with $\mathrm{Cr}(\mathrm{III})$ and $\mathrm{Cr}(\mathrm{VI})$ relative to non-amended treatments.

Acknowledgments The research was conducted as part of project no. N305 105933 and supported by the Polish Ministry of Science and Higher Education.

Open Access This article is distributed under the terms of the Creative Commons Attribution 4.0 International License (http:// creativecommons.org/licenses/by/4.0/), which permits unrestricted use, distribution, and reproduction in any medium, provided you give appropriate credit to the original author(s) and the source, provide a link to the Creative Commons license, and indicate if changes were made.

\section{References}

Adejumo SA, Ogundiran MB, Togun AO (2018) Soil amendment with compost and crop growth stages influenced heavy metal uptake and distribution in maize crop grown on lead-acid battery waste 
contaminated soil. J Environ Chem Eng 6(4):4809-4819. https:// doi.org/10.1016/j.jece.2018.07.027

Ahmad M, Lee SS, Yang JE, Rob HM, Lee YH, Ok YS (2012) Effects of soil dilution and amendments (mussel shell, cow bone, and biochar) on $\mathrm{Pb}$ availability and phytotoxicity in military shooting range soil. Ecotoxicol Environ Saf 79:225-231. https://doi.org/10.1016/j. ecoenv.2012.01.003

Antoniadis V, Zanni AA, Levizou E, Shaheen SM, Dimirkou A, Bolan N, Rinklebe J (2018) Modulation of hexavalent chromium toxicity on Origanum vulgare in an acidic soil amended with peat, lime, and zeolite. Chemosphere 195:291-300. https://doi.org/10.1016/j. chemosphere.2017.12.069

Arfaeinia H, Dobaradaran S, Moradi M, Pasalari H, Mehrizi EA, Taghizadeh F, Esmaili A, Ansarizadeh M (2019) The effect of land use configurations on concentration, spatial distribution, and ecological risk of heavy metals in coastal sediments of northern part along the Persian Gulf. Sci Total Environ 653:783-791. https://doi.org/10. 1016/j.scitotenv.2018.11.009

Cameselle C, Gouveia S (2019) Phytoremediation of mixed contaminated soil enhanced with electric current. J Hazard Mater 361:95-102. https://doi.org/10.1016/j.jhazmat.2018.08.062

Cavell AJ (1955) The colorimetric determination of phosphorous in plant materials. J Sci Food Agric 6:479-481

Chen H, Dou J, Xu H (2018) The effect of low-molecular-weight organicacids (LMWOAs) on treatment of chromium-contaminated soils by compost-phytoremediation: kinetics of the chromium release and fractionation. J Environ Sci 70:45-53. https://doi.org/10.1016/j.jes. 2017.11.007

Chu Y, Liu S, Wang F, Bian H, Cai G (2018) Electric conductance response on engineering properties of heavy metal polluted soils. $\mathrm{J}$ Environ Chem Eng 6(4):5552-5560. https://doi.org/10.1016/j. jece.2018.08.046

Dotaniya ML, Rajendiran S, Meena VD, Saha JK, Vassanda Coumar M, Kundu S, Patra AK (2017) Influence of chromium contamination on carbon mineralization and enzymatic activities in vertisol. J Agric Res 6(1):91-96. https://doi.org/10.1007/s40003-016-0242-6

Elouahli A, Zbair M, Anfar Z, Ahsaine HA, Khallok H, Choura R, Hatim Z (2018) Apatitic tricalcium phosphate powder: high sorption capacity of hexavalent chromium removal. Surf Int 13:139-147. https://doi.org/10.1016/j.surfin.2018.09.006

Eyvazi B, Jamshidi-Zanjani A, Darban AK (2019) Immobilization of hexavalent chromium in contaminated soil using nanomagnetic $\mathrm{MnFe}_{2} \mathrm{O}_{4}$. J Hazard Mater 365:813-819. https://doi.org/10.1016/j. jhazmat.2018.11.041

Feng W, Wan Z, Daniels J, Li Z, Xiao G, Yu J, Xu D, Guo H, Zhang D, May EF, Li GK (2018) Synthesis of high quality zeolites from coal fly ash: mobility of hazardous elements and environmental applications. J Clean Prod 202:390-400. https://doi.org/10.1016/j.jclepro. 2018.08.140

Goswami L, Mukhopadhyay R, Bhattacharya SS, Das P, Goswami R (2018) Detoxification of chromium-rich tannery industry sludge by Eudrillus eugeniae: insight on compost quality fortification and microbial enrichment. Bioresour Technol 266:472-481. https://doi. org/10.1016/j.biortech.2018.07.001

Gupta P, Kumar V, Usmani Z, Rani R, Chandra A (2018) Phosphate solubilization and chromium (VI) remediation potential of Klebsiella sp. strain CPSB4 isolated from the chromium contaminated agricultural soil. Chemosphere 192:318-327. https://doi.org/ 10.1016/j.chemosphere.2017.10.164

Hamid Y, Tang L, Yaseen M, Hussain B, Zehra A, Aziz MZ, He Z, Yang $X$ (2019) Comparative efficacy of organic and inorganic amendments for cadmium and lead immobilization in contaminated soil under rice-wheat cropping system. Chemosphere 214:259-268. https://doi.org/10.1016/j.chemosphere.2018.09.113

He X, Zhong P, Qiu X (2018) Remediation of hexavalent chromium in contaminated soil by $\mathrm{Fe}(\mathrm{II})-\mathrm{Al}$ layered double hydroxide.
Chemosphere 210:1157-1166. https://doi.org/10.1016/j. chemosphere.2018.07.048

He D, Cui J, Gao M, Wang W, Zhou J, Yang J, Wang J, Li Y, Jiang C, Peng Y (2019) Effects of soil amendments applied on cadmium availability, soil enzyme activity, and plant uptake in contaminated purple soil. Sci Total Environ 654:1364-1371. https://doi.org/10. 1016/j.scitotenv.2018.11.059

Hedayatkhaha A, Cretoiud MS, Emtiazic G, Stala LJ, Bolhuis H (2018) Bioremediation of chromium contaminated water by diatoms with concomitant lipid accumulation for biofuel production. $J$ Environ Manag 227:313-320. https://doi.org/10.1016/j.jenvman.2018.09. 011

Hseu ZY, Zehetner F, Fujii K, Watanabe T, Nakao A (2018) Geochemical fractionation of chromium and nickel in serpentine soil profiles along a temperate to tropical climate gradient. Geoderma 327:97106. https://doi.org/10.1016/j.geoderma.2018.04.030

Hu J, Meng DL, Liu HD, Liang YL, Yin HQ, Liu HW (2018) Response of soil fungal community to long-term chromium contamination. Trans Nonferrous Metals Soc China 28(9):1838-1846. https://doi. org/10.1016/S1003-6326(18)64828-9

Huang HL, Wei YJ (2018) Speciation of chromium compounds from humic acid-zeolite $\mathrm{Y}$ to an ionic liquid during extraction. Chemosphere 194:390-395. https://doi.org/10.1016/j. chemosphere.2017.11.160

Jobby R, Jha P, Yadav AK, Desai N (2018) Biosorption and biotransformation of hexavalent chromium [Cr(VI)]: a comprehensive review. Chemosphere 207:255-266. https://doi.org/10.1016/j.chemosphere. 2018.05.050

Kintl A, Elbl J, Losak T, Vaverková MD, Nedelnik J (2018) Mixed intercropping of wheat and white clover to enhance the sustainability of the conventional cropping system: effects on biomass production and leaching of mineral nitrogen. Sustainability 10(10):3367. https://doi.org/10.3390/su10103367

Kjeldahl JZ (1983) A new method for the determination of nitrogen in organic matter. Anal Chem 22:366

Krzyżaniak M, Stolarski MJ, Warminski K (2019) Life cycle assessment of poplar production.: environmental impact of different soil enrichment methods. J Clean Prod 206:785-796. https://doi.org/10.1016/ j.jclepro.2018.09.180

Kust G, Andreeva O, Lobkovskiy V, Telnova N (2018) Uncertainties and policy challenges in implementing Land Degradation Neutrality in Russia. Environ Sci Pol 89:348-356. https://doi.org/10.1016/j. envsci.2018.08.010

Lee CP, Hsu PY, Su CC (2019) Increased prevalence of Sjogren's syndrome in where soils contain high levels of chromium. Sci Total Environ 657:1121-1126. https://doi.org/10.1016/j.scitotenv.2018. 12.122

Li X, Wang X, Chen Y, Yang X, Cui Z (2019) Optimization of combined phytoremediation for heavy metal contaminated mine tailings by a field-scale orthogonal experiment. Ecotoxicol Environ Saf 168:1-8. https://doi.org/10.1016/j.ecoenv.2018.10.012

Lilli MA, Nikolaidis NP, Karatzas GP, Kalogerakis N (2019) Identifying the controlling mechanism of geogenic origin chromium release in soils. J Hazard Mater 366:169-176. https://doi.org/10.1016/j. jhazmat.2018.11.090

Liu HL, Zhoua J, Lia M, Hua YM, Liud X, Zhou J (2019) Study of the bioavailability of heavy metals from atmospheric deposition on the soil-pakchoi (Brassica chinensis L.) system. J Hazard Mater 362:916. https://doi.org/10.1016/j.jhazmat.2018.09.032

Majewski G, Kleniewska M, Brandyk A (2011) Seasonal variation of particulate matter mass concentration and content of metals. Pol J Environ Stud 20(2):417-427

Patra DK, Pradhan C, Patra HK (2018) An in situ study of growth of Lemongrass Cymbopogon flexuosus (Nees ex Steud.) W. Watson on varying concentration of Chromium $\left(\mathrm{Cr}^{+6}\right)$ on soil and its bioaccumulation: perspectives on phytoremediation potential and 
phytostabilisation of chromium toxicity. Chemosphere 193:793799. https://doi.org/10.1016/j.chemosphere.2017.11.062

Paul D, Choudhary B, Gupta T, Jos MT (2015) Spatial distribution and the extent of heavy metal and hexavalent chromium pollution in agricultural soils from Jajmau, India. Environ Earth Sci 73:35653577. https://doi.org/10.1007/s12665-014-3642-6

Radziemska M, Mazur Z (2016) Content of selected heavy metals in Nicontaminated soil following the application of halloysite and zeolite. Journal of Ecological Engineering 17(3):125-133. https://doi.org/ $10.12911 / 22998993 / 63336$

Radziemska M, Gusiatin ZM, Bilgin A (2017a) Potential of using immobilizing agents in aided phytostabilization on simulated contamination of soil with lead. Ecol Eng 102:490-500. https://doi.org/ 10.1016/j.ecoleng.2017.02.028

Radziemska M, Vaverková MD, Baryła A (2017b) Phytostabilization management strategy for stabilizing trace elements in contaminated soils. Int J Environ Res Public Health 14(9):958. https://doi.org/10. 3390/ijerph14090958

Raptis S, Gasparatos D, Economou-Eliopoulos M, Petridis A (2018) Chromium uptake by lettuce as affected by the application of organic matter and $\mathrm{Cr}(\mathrm{VI})$-irrigation water: implications to the land use and water management. Chemosphere 210:597-606. https://doi.org/ 10.1016/j.chemosphere.2018.07.046

Saleem M, Asghar HN, Khan MY, Zahir ZA (2015) Gibberellic acid in combination with press mud enhances the growth of sunflower and stabilizes chromium(VI)-contaminated soil. Environ Sci Pollut Res 22:10610-10617. https://doi.org/10.1007/s11356-015-4275-3

Shahid M, Shamshad S, Rafiq M, Khalid S, Bibi I, Niazi NK, Duma C, Rashid MI (2017) Chromium speciation, bioavailability, uptake, toxicity and detoxification in soil-plant system: a review. Chemosphere 178:513-533. https://doi.org/10.1016/j. chemosphere.2017.03.074
Sinha V, Pakshirajan K, Chaturvedi R (2018) Chromium tolerance, bioaccumulation and localization in plants: an overview. J Environ Manag 206:715-730. https://doi.org/10.1016/j.jenvman.2017.10. 033

Szyszko E (1982) Instrumental analytical method. PZWL, Warsaw, p 623

US Environmental Protection Agency (2007) Method 3051A, Microwave assisted acid digestion of sediments, sludges, soils and oils. Washington, DC

Walkley A, Black IA (1934) An examination of the Degtjareff method for determining soil organic matter, and a proposed modification of the chromic acid titration method. Soil Sci 37:29-38

Wyszkowski M, Radziemska M (2009) The effect of chromium content in soil on the concentration of some mineral elements in plants. Fresenius Environ Bull 18(7):1039-1045

Wyszkowski M, Radziemska M (2013) Assessment of tri- and hexavalent chromium phytotoxicity on oats (Avena sativa L.) biomass and content of nitrogen compounds. Water Air Soil Pollut 244:1619-1632. https://doi.org/10.1007/s11270-013-1619-9

Yin Y, Gu J, Wang X, Song W, Zhang K, Zhang X, Lu C, Liu J (2018) Effects of chromium (III) on enzyme activities and bacterial communities during swine manure composting. Bioresour Technol 243: 693-699. https://doi.org/10.1016/j.biortech.2017.06.169

Molla A, Ioannou Z, Mollas S, Skoufogianni E, Dimirkou A (2017) Removal of chromium from soils cultivated with maize (Zea mays) after the addition of natural minerals as soil amendments. Bull Environ Contam Toxicol 98:347-352. https://doi.org/10.1007/ s00128-017-2044-3

Publisher's note Springer Nature remains neutral with regard to jurisdictional claims in published maps and institutional affiliations. 